\title{
Corrigendum
}

\section{Carcass traits of male and female Creole goats according to slaughter weights, preliminary results - CORRIGENDUM}

\author{
Willy Cei, Jean-Christophe Bambou, Maurice Mahieu and Gisèle Alexandre
}

doi:10.1017/S2040470010000245; published by Cambridge University Press, 8 November 2010

In the abstract by Willy Cei, Jean-Christophe Bambou, Maurice Mahieu and Gisèle Alexandre (2010) presented in Advances in Animal Biosciences, the following text was missing:

\section{Conclusion}

From these preliminary results, the Creole goat could be defined as a lean meat animal with satisfactory carcass traits and yield. Further research is required to improve the feeding management and to test the effect of parasitism on performances and meat quality. It will be interesting to enlarge the data base with more M kids (the F kids must be kept for reproduction) and more heavy animals.

\section{References}

Alexandre G and Mandonnet N 2005. Goat meat production in harsh environments. Small Ruminant Research 60, 53-66.

Cameron MR, Hart SP, Sahlu T, Gilchrist C and Coleman SW 2001. Effects of gender and age on performance and harvest traits of Boer $x$ Spanish goats. Journal of Applied Animal Research 20, 141-155.

Liméa L, Bocage B, Arquet R, Mahieu M and Alexandre G 2009. Carcass conformation and cut composition of Creole goat from Guadeloupe. Tropical Animal Health and Production 42, 507-514.

Pena F, Perea J, Garcia A and Acero R 2007. Effects of weight at slaughter and sex on the carcass characteristics of Florida suckling kids. Meat Science 75, 543-550. Webb EC, Casey NH and Simela L 2005. Goat meat quality. Small Ruminant Research 60, 153-166.

The editors apologise to the authors and readers for this mistake.

\section{Reference}

Cei W, Bambou J-C, Mahieu M and Alexandre G 2010. Carcass traits of male and female Creole goats according to slaughter weights, preliminary results. Advances in Animal Biosciences 1, 396-397. 